\title{
Recognition in International Law: A Functional Reappraisal†
}

The ambiguous nature of the doctrine of recognition in international law has contributed to significant academic dispute. ${ }^{1}$ At least two major theories have been advanced to provide a framework for this part of international law. The "constitutive theory" views recognition as the voluntary act of the recognizing state; the "declaratory theory" accepts recognition as automatic. ${ }^{2}$

Recognition has both legal and political meanings, both internal and external consequences for the recognizing state. ${ }^{3}$ The law which applies in one set of circumstances may not necessarily apply in another. In strictly public international law acceptance of a declaratory theory requiring immediate admission of the fact of existence of a foreign state seems necessary. If, however, domestic legal issues are also involved, a state may legitimately impose other conditions of its own law and policy, resulting in the operation of some elements of a constitutive standard. Such a distinction can readily be discerned within the existing law. It is consistent both with the maintenance of international order and with the protection of domestic legal integrity.

\section{Clarification of Terminology}

A restricted vocabulary has been used to describe a large quantity of concepts. One distinction traditionally made in the literature is that between recognition of a state and recognition of a government. In the traditional jurisprudence the state is the unit or persona of international law which is capable of holding rights within the system. ${ }^{4}$ A new

$\dagger$ Fred L. Morrison, A.B. 1961, University of Kansas; B.A. 1963, Oxford University; M.A. 1965, Ph.D. 1966, Princeton University; J.D. 1967, University of Chicago.

1 The most significant of the recent academic examinations of this subject have been Chen, The International LAw of Recognition (1951); LAUTERPacht, RECOGNition in INTERnational LAW (1947); Patel, Recognirion in the LAW OF Nations (1959); and Kelsen, Recognition in International Law: Theoretical Observations, 35 AM. J. INT'L L. 605 (1941).

2 An explanation of the two theories is undertaken later. See text accompanying notes 14-44 infra.

3 Kelsen, supra note 1, makes the latter distinction, but does not follow it through.

4 This does not prevent the creation of new personae, e.g. international organizations, within the system. Cf. text accompanying note 70 infra. 
state appears within the system only upon the bifurcation or dissolution of some other state or empire. ${ }^{5}$ With the extinction of these empires, the problems of state recognition are becoming more matters of legal history than living problems of practical consequence. ${ }^{6}$ The recognition of governments has been treated as a different matter. Governments are mere agents of the primary abstract entity, the state. ${ }^{7}$ Where governments or heads of state succeed one another through the constitutional processes of the society, there is normally no official notice taken of the transition. ${ }^{8}$ Where, however, violent or substantial changes in the constitutional structure take place, a decision must be made by each external state whether to recognize the new authorities. ${ }^{9}$ The problem is especially difficult when internal war results in the existence over a prolonged period of two or more authorities each controlling a substantial segment of the territory and purporting to act for the state as a whole.

The formal difference between recognition of states and recognition of governments is considerable. The fundamental rights of a recognized state, e.g., territorial integrity, are protected even though it does not have a recognized government; an unrecognized state may not even have these minimal rights. The practical difference is, however, unimportant. Nonrecognition of a new state is normally concomitant with acknowledgement that the territory thereof is rightfully within the sovereignty of some third power. Any conflict thus becomes simply an internal power struggle, and any extraneous government which intervenes will do so as an "ally" of one of the contesting factions. This comment will attempt to minimize the importance of the distinction between these two types, but will concentrate upon the recognition of governments. With only a few exceptions, state recognition has been accompanied by governmental recognition. ${ }^{10}$

Two frequent confusions of terminology should be mentioned here.

5 Thus, after the First World War, a number of Eastern European states arose out of the ruins of the Russian and Austro-Hungarian empires, while more recently African and Asian states have emerged from the dissolution of colonial empires.

6 The dissolution of post-colonial federations, like Malaysia (from which Singapore claimed its independence) and Nigeria, might offer new vitality for an old distinction.

$\tau$ " $I t$ is a fundamental rule of international law that every independent State is entitled to be represented in the international sphere by a government ... " LAUTERPACHT, op. cit. supra note 1, at 87. Cf. CHEN, op. cit. supra note 1, at 97-104.

8 E.g., the succession of one duly elected British government for another. In cases like the Greek military coup of 1967, an assumption of "constitutionality" may save a recognizing state from making embarrassing diplomatic and political statements.

9 The state may continue to be recognized, without the recognition of any particular government.

10 Among the exceptions are the Eastern European states which were recognized after the First World War before their governments were recognized. 
One is caused by the unfortunately vague use of the words de facto and de jure. The distinction between these terms has been made at least three ways. ${ }^{11}$ Because of the inherent confusion involved in their use, these terms will not be used. A second confusion is between recognition and the establishment of diplomatic relations. ${ }^{12}$ While the establishment of diplomatic relations implies recognition, recognition can exist without diplomatic intercourse. ${ }^{13}$

\section{Traditional Doctrines}

The two major traditional doctrines regarding the recognition of states are the constitutive and the declaratory. Some authors have succeeded in moderating their viewpoints by compromising elements of both approaches into a consistent doctrine. ${ }^{14}$ This comment will seek to follow the same course.

The constitutive view is largely dominated by legal positivists.

11 One distinction was proposed by the 1936 session of the Institut de Droit International: the term de facto should be used to describe "provisional or limited" recognition, and the term de jure should be used to describe "definite or complete" recognition. Institut de Droit International, Resolutions Concerning the Recognition of New States and New Governments, reprinted in 30 AM. J. INT'L L. SUPP. 185, 186 (1936). Since all recognition is subject to withdrawal upon the termination of statehood, this seems little more than a suggestion that the permanence of a state or government is questionable. It has no clear juristic consequences.

A second usage of the terms is more judicial in origin. Some courts have used de facto to describe a government which does, as a matter of fact, exist, but with which the foreign office of the foreign state has no official relations. De jure governments are those certified by the foreign office to be legitimate and with which it has official relations. See, e.g., the certificate of the British Foreign Office, The Arantzazu Mendi, [1938] P. 233, 242.

The third usage is frankly political. "De facto" is sometimes used by foreign offices or politicians to describe a government which clearly exists, but which does not measure up to the standards of legitimacy which that office or person requires of others. In the nineteenth century the standard was one of legal continuity, rejecting revolutionary changes unacknowledged by the "parent" state. See generally, Alexandrowicz, The Theory of Recognition in Fieri, 34 BRTT. Y.B. INT'L L. 176 (1958); Lyons, The Conclusiveness of the Foreign Office Certificate, 23 BRrr. Y.B. INT'x L. 240 (1946). More recently, the United States has used such a policy to deny recognition to nonpopular revolutionary governments in Latin America. It also had effect in the Stimson Doctrine of nonrecognition of territorial changes accomplished through aggressive action, in which the United States joined the League of Nations. Cf. Williams, Some Thoughts on the Doctrine of Recognition in International Law, 47 HARv. L. REv. 776, 781 (1934).

$12 C f$. text accompanying notes 72-74 infra.

13 Similarly, suspension of diplomatic relations does not imply suspension of recognition. Banco Nacional de Cuba v. Sabbatino, 376 U.S. 398, 408-12 (1964). Cf. the certificate in Banco Para el Comercio Exterior de Cuba v. Steamship Ruth Ann, 228 F. Supp. 501, 503-05 (D.P.R. 1964). And there are means other than entry into diplomatic relations to confer recognition. See Graham, The League of Nations and the Recognition of States, 3 FAculty Research Lectures of U.C.I.A. I, 31 (1933); Kunz, Die ANerkenNung von StAATEN und REGIERUNGEN IM VÖLKERRECHT 20-25 (1928).

14 LAUTERPACHT, op. cit. supra note 1 , is an example. 
Kelsen, ${ }^{15}$ Anzilotti, ${ }^{16}$ Triepel, ${ }^{17}$ Wheaton, ${ }^{18}$ and Oppenheim ${ }^{18}$ can be cited in support of it. As Oppenheim stated, the constitutive theory provides that: "A state is and becomes an international person through recognition only and exclusively." 20 Thus a new state can acquire rights and duties in international law only when older states formally recognize it. The emphasis is on the formal act of recognition, rather than upon any factual basis which there may be to support it. Even though it may possess all of the other criteria of statehood, a new community cannot claim to participate in international law until there has been a formal act of recognition. An analogy can be drawn to the creation of a corporation in domestic legal systems through the formal act of chartering.

This positivism provides a basis for obligation in international law. By describing the first act of recognition as a pactum, the theorist can infer consent to all customary international law and thus reduce the system to one basic principle: pacta sunt servanda. ${ }^{21}$ While this legal fiction provides a method of tying new states to an existing international order, its own artificiality is a serious weakness. Should there not be more firm basis of obligation than mere implied consent? Under the strict constitutive view there can be no "duty" to recognize,22 because there is no one to whom that "duty" might be owed until after the act of recognition itself. ${ }^{23}$

The two basic criticisms of the constitutive theory are that it is logically unsound and morally objectionable. The constitutive theory brings a state from nothingness into being by the mere act of recognition. ${ }^{24}$ Accordingly, a new state will "exist" as to those states which

15 Kelsen, supra note 1.

16 Anztlotti, Cours de Drotr International $159-77$ (3d ed. French transl. 1929).

17 TRIEPEI, VOLKERRECHT UND LANDESRECHT 63-81 (1899).

18 Wheaton, Elements of International Law 30-31 (6th ed. 1855). See also Wheaton, ELEMENTS OF INTERNATIONAL LAW 38-48 (6th English ed. Keith 1929).

19 I Oppenheim, International Law: A Treatise 109 (1905).

20 Id. at 119.

21 ANZILOTrI, op. cit. supra note 16, at 161; cf. Triepel's Vereinbarung, TrIEPEL op. cit. supra note 17 , at $63-81$.

22 It is here that Lauterpacht departs from the strict constitutive theory, admitting a duty of the older states to perform the constitutive act. LAUTERPACHT, op. cit. supra note 1, at 26-37, 73-77.

23 "Is an existing state obliged to recognize a new community as a state, if this new community, according to the opinion of the existing state, fulfills the conditions laid down by international law? Such an obligation, however desirable, is not stipulated by international law. Existing states are only empowered-they are not obliged-to perform the act of recognition." Kelsen, supra note 1, at 609-10.

24 "Whether one likes the situation or not from the political or moral angle, a state is compelled diplomatically or judicially to take notice de facto or de jure of the existence of another state. Any other attitude lends to such absurdities of pretending that at a 
recognize it, while not existing as to those states which do not. The artificiality thus introduced is a serious flaw in a system of law directed at practical relationships. Furthermore, the constitutive view is unable to deal with the recognition of governments on the same footing as the recognition of states. Governments clearly cannot be "constituted" by the recognizing state, although they can be admitted to the rights which the pre-existing state possessed. ${ }^{25}$

The more serious objections to the theory are based on its moral implications. Nonrecognition of a state means that the citizens of that state may not be protected by international law, either in war or in peace. This, indeed, is Lauterpacht's main objection to the strict constitutive theory. ${ }^{28}$ The "family of nations" would become merely a mutual admiration society. Nonrecognition (which, one must remember, is discretionary) could serve as a license for invasion without legal responsibility. ${ }^{27}$

The opposing view is the "declaratory." It is supported by writers who have less commitment to the consistency of legal dogmatism than to the efficacy of a legal order. Brierly, ${ }^{28}$ Moore, ${ }^{29}$ Verdross, ${ }^{30}$ Chen, ${ }^{31}$ $\mathrm{Kunz}^{32}$ and Briggs ${ }^{33}$ can be listed in support of this theory. The basic tenet of the approach is that international law is an objective system, which dictates the conditions upon which a state becomes a member of the international community. When a state has fulfilled these conditions, it automatically becomes subject to the rights and duties of international law, without any formal action on the part of the other members of the international system. As Moore says, "The rights and attributes of sovereignty belong to it independently of all recognition, but it is only after it has been recognized that it is assured of exercising them."34 Much as an infant attains majority without express recogni-

given moment something does not exist and, then, by a magic flourish of a pen, it comes into being-as if you revived a mummy." Brown, The Effects of Recognition, 36 AM. J. INT'L L. 106, 107 (1942).

25 Another absurdity thus results: nonrecognition of a government in a recognized state may be an international delict, but nonrecognition of the state itself cannot be. $C f$.

Kelsen, supra note 1, at 614-16.

26 LAUTERPACHT, op. cit. supra note 1, at 52-55.

27 Kunz, Die ANerkennung von StaAten und Regierungen im Völkerrecht 89 (1928), gives examples of the type of reasoning which would justify aggressive attacks under the constitutive theory.

28 BRIERLY, THE LAW OF NATTONS 81-85 (1928).

291 Moore, A Digest of INTERnational LAW 72-74 (1906).

30 VERDROSS, VöLKERRECHT 158-91 (1950).

31 CHEN, op. cit. supra note 1.

$32 \mathrm{KuNZ}$, op. cit. supra note 27 .

33 The LAW OF NAtions 113-17, $125-32$ (Briggs ed. 1952).

341 MOORE, A Digest OF INTERNATIONAL LAW 72 (1906). 
tion in most domestic systems, a community which has satisfied the objective conditions of international law obtains statehood. This necessitates a set of objective standards; the traditional ones are population, territory, independence, and the existence of a government. ${ }^{35}$ Examples of the declaratory approach can be found both in a 1936 statement of the Institut de Droit International ${ }^{36}$ and in the Charter of the Organization of American States. ${ }^{37}$

The declaratory approach has the advantage of directly accommodating the problems of governmental recognition. Governments clearly cannot be "constituted" by recognition, but their existence can be made known by declaratory action of the recognizing states. The approach is closely related to the so-called Estrada Doctrine, ${ }^{38}$ enunciated by Mexico in 1931 in response to repeated interference by the United States in Latin American affairs through a policy of selective recognition. ${ }^{39}$ Under this policy, the external state simply deals with whatever government has power in the "recognized" state, without political preconditions or express declarations. ${ }^{40}$

35 Cf. LAUTERPACHT, op. cit. supra note 1, who lists independent government, effective authority, and defined territory, assuming the population point.

36 Article 1 states: "The recognition of a new state is the free act by which one or more States acknowledge the existence on a definite territory of a human society politically organized, independent of any other existing State, and capable of observing the obligations of international law, and by which they manifest therefore their intention to consider it a member of the international community.

"Recognition has a declaratory effect.

"The existence of a new State with all the juridical effects which are attached to that existence, is not affected by the refusal of recognition by one or more states." Institut de Droit International, Resolutions Concerning the Recognition of New States and New Governments, reprinted in 30 AM. J. INT'L L. SuPP. 185 (1936).

37 Article 9 of the Charter of the Organization of American States provides: "The political existence of the State is independent of recognition by other States. Even before being recognized, the State has the right to defend its integrity and independence, to provide for its preservation and prosperity, and consequently to organize itself as it sees fit, to legislate concerning its interests, to administer its services, and to determine the jurisdiction and competence of its courts. The exercise of these rights is limited only by the exercise of the rights of other states in accordance with international law." [1951] 2 U.S.T. \& O.I.A. 2416, 2419.

38 Under the Estrada Doctrine, the Mexican government announced that it was "issuing no declarations in the sense of grants of recognition, since that nation [Mexico] considers that such a course is an insulting practice and one which, in addition to the fact that it offends the sovereignty of other nations, implies that judgment of some sort may be passed upon the internal affairs of those nations by other governments." Estrada Doctrine of Recognition, 25 AM. J. INT'L L. SUPP. 203 (1931).

39 El Problema del Reconocimiento de Gobiernos Extranjeros, LA OPINION UNIVERSAL SOBRE LA DOCTRINa Estrada 7 (1931).

40 The doctrine has its own peculiar pitfalls. Some authority in the "recognizing state" must make a determination as to which of two competing regimes in the other state is to be treated as the government of that state. Where there is continuing civil strife, and particularly where the old government wages a prolonged but losing defensive action, such 
While the declaratory approach operates well in the field of what is strictly public international law, it does not adequately deal with those private law questions in which public international law may be marginally involved. ${ }^{41}$

Some attempts have been made to combine the best features of both of the approaches to the problem of recognition. Lauterpacht starts from a constitutive basis, but then imposes a duty upon each of the preexisting states to grant recognition to a new community when it has satisfied certain objective criteria, thus importing a declaratory element. ${ }^{42}$ Both Kunz ${ }^{43}$ and Patel ${ }^{44}$ have criticized this as a confusion of actual and ideal international law. They claim that the theory which Lauterpacht propounds might adequately serve the international community, but that it does not represent the present state of the law.

\section{A PROPOSED VIEW}

The thesis of this comment is that both approaches to the nature of recognition are appropriate within their own limited spheres, and that the term "recognition" covers too many concepts which may usefully be distinguished. Both the traditional approach to international law, with its reliance on state practice, arbitral and judicial decisions, treaties, and agreements, ${ }^{45}$ and the "sociological" approach, based on the functional requisites for an ordered international society, ${ }^{46}$ support the distinctions proposed.

In discussing the standards established in positive international law in the traditional jurisprudence, one should carefully distinguish two interrelated levels of applicability. The first is that minimum standard of state action which is prescribed by the general international law for all states and established by customary practice or explicit agreement. The second level is that standard which a nation actually imposes upon itself, which may be termed the particular international law of the

a determination will be important. The Estrada doctrine seems best adapted to those cases in which there is an abrupt and clear change of power with a new government quickly in a position of relative stability-like the typical Latin American coup.

41 Cf. text accompanying notes 81-115 infra.

42 LAUTERPACHT, op. cit. supra note 1 , at 6; cf. LAUTERPACHT-OPPENHEIM, INTERNATTONAL LAW 120-46 (6th ed. 1947).

43 As Kunz says: "But Lauterpacht's principal thesis, . . . his assertion of a right of recognition and a duty to recognize, is certainly entirely untenable as not being in accord with positive international law." Kunz, Critical Remarks on Lauterpacht's "Recognition in International Law," 44 AM. J. INT'L L. 713 (1950).

44 PATEL, op. cit. supra note I, at 23-33.

45 As typified by such writers as Brierly and by the casebook approach of authors such as Briggs and Bishop.

46 The leading exponent of this school is certainly Professor Myres McDougal. 
state concerned. ${ }^{47} \mathrm{~A}$ violation of the standards of general international law by a state is a delict against the state whose interests have been harmed. A violation of the standards of particular international law in some state, which is not also a violation of the general standard, can only be a transgression of the internal norms of that state. ${ }^{48}$ Such a distinction is not subversive of international order. A state may easily prescribe a standard in dealing with international affairs which is higher than that actually required by the general international law. Of course, if a state provides less protection than international standards require, it commits an international delict if it applies its laws without reference to the general standard.

The two standards are interrelated. A particular standard of law may simply incorporate the general system as its body of rules governing international transactions. ${ }^{49}$ On the other hand, particular systems which differ from the prevailing general system may incite implicit change in the general system, either increasing or decreasing the protection of the general law. ${ }^{50}$ In examining the jurisprudence of municipal courts and foreign offices, it is therefore necessary to discover how far the court or office is operating by a standard which is common to all or most international actors (and binding because part of the general system of laws) and to what extent it is operating only under a selfimposed legal standard or bureaucratic routine not common to the international system or to some regional system (and binding only because imposed by the particular municipal authority).

When there is an actual confrontation of states, the general standard of international law must apply to settle their respective rights and duties; in these cases, the standard of recognition is declaratory. When, on the other hand, the confrontation is one over property rights or over access to the courts in one state by the government of another, the forum state may impose its own particular standard of international

47 For an example, see In re Piracy Jure Gentium, [1934] A.C. 586 (P.C.). There the Judicial Committee of the Privy Council found that international law would allow the British government to arrest and try a larger class of persons as "pirates" than British law itself permitted.

48 While not directly an international delict, it might raise liability for denial of justice.

49 Most systems apparently do so. For an example of a specific direction to the courts to incorporate standards of general international law in their decisions (and to ignore the "act of state" doctrine of the particular international law of the United States), see 22 U.S.G. $\S 2370(e)(2)(1964)$.

50 E.g., while the first claim to a twelve mile zone of territorial waters may have been clearly contrary to the then prevailing general international standard, the persistence and repetition of such claims by other states may have begun to modify the general international standard even before the Geneva Convention on the Territorial Sea, [1964] 2 U.S.T. \& O.I.A. 1606. 
law; in appropriate circumstances this may be a constitutive standard. The presentation which follows will be divided into three parts. The first of these will deal with the rights and duties, strictly speaking, of states and governments in their dealings with one another within the framework of general international law not involving the adjudication of private rights within one of the states. The second will deal with political questions, where there are no strict rights and duties. The final section will deal with questions arising in domestic tribunals relating to actions or property of other states within the forum state.

\section{A. The External Sphere of Action: Strict Law}

General international law most properly affects the relations of states with one another. Other than marginally, it does not confer rights or duties upon individuals. ${ }^{51}$ It is the only standard which binds the recognizing (or nonrecognizing) state in connection with acts external to its own territory and directly in relation to some new state or government. It does not extend to matters in the law of the recognizing state or to physical objects within its territory. State responsibility for denial of justice and the law of sovereign immunity may be viewed as exceptions to this rule. Nor does the general standard extend to political questions, such as the decision to deal diplomatically with some new state or government other than on the basis of strict legal rights.

General international law does include the responsibility of a state to respect the sovereign territory of a foreign state, to respect the rights of the other party in neutral places (as on the high seas), and to admit the other party to the benefits of the laws of war and other customary international law. It even includes responsibility for "denial of justice," although it does not interfere in domestic judicial processes except to impose a state responsibility for damages. ${ }^{62}$ It is submitted that the international law of recognition on all of these questions both is, by positive international law, and must be, from the needs of the international community, declaratory in nature.

International law seems to require respect for the territory of a foreign state whether or not that state (or its government) is recog-

51 The Law of Nations 93-98 (Briggs ed. 1952), summarizes the literature on this subject. It is clear that international law is moving away from requiring that only a state may have rights, and is giving rights to individuals or groups, e.g., by the protection against genocide.

52 BrIGGs, id. at 51,64 , postulates the case in which the municipal law and the international law cannot be reconciled: "[T] he municipal court, whose authority is derived from municipal law, will apply municipal law. ... Whether or not this involves the State in a violation of international law depends upon the steps taken by other branches of the government to remedy the wrong." See generally $i d$. at 60-65. 
nized. ${ }^{53}$ State practice regarding recognition of territorial integrity is apparently such that few cases arise. Any state which intervenes in the territory of another in which it does not recognize the incumbent government normally does so at the request of the former sovereign. In so doing, it acts merely as an ally of that sovereign. As an ally, it can claim the rights of its principal, and that principal can in turn rely on its title of legitimacy. ${ }^{54}$ For the former sovereign, nonrecognition is only evidence of a more pervasive claim to exclusive jurisdiction over the territory. Few cases have arisen, it is suggested, because states have followed the only practicable course and have treated governments actually in power (whether recognized or not) with all of the respect due them in international law, whether or not this is publicly admitted. ${ }^{55}$ Any other solution would lead to the admission of the legality of hostile confrontations. The nearly uniform state practice here must evidence a general rule of international law.

The more modern jurisprudence would seem to dictate a similar answer. Since recognition is an artificial concept, nonrecognition cannot be used to justify military action disturbing world order.

Again, in the use of the high seas, few cases have actually arisen in international law. Practice simply does not allow seizure of ships for "failure to display a recognized flag," although it certainly does allow seizure for failure to display any flag at all. ${ }^{56}$ American authorities, for example, would apparently not consider East German shipping "piratical," and therefore subject to seizure, even though the recognized West German government might approve of that action. Realistic considerations have dictated behavior which is consistent in act, if not in profession, with the declaratory theory. These same considerations dictate a result in strict law which is consonant with this practice.

Indeed, in this field of activity in neutral places, international law has provided a mechanism for official public allowance of the claims of rebellious groups to equal treatment in international areas through

53 The most recent Arab-Israeli conflict illustrates this point cogently. When a state (e.g., Israel) exists in fact, military action against it will be international war, whether other nations (e.g., the Arab states) recognize it or not. Only by the use of a declaratory theory can such conflicts be prevented.

54 And it must stand or fall according to the propriety of that action.

55 Consider the case of the involvement of the United States in Viet Nam. While the United States does not recognize the government of North Viet Nam, it has treated it as a foreign state and has avoided land attacks upon its territory. It has, indeed, tended to justify the air attacks against the North in terms of necessary defensive measures for the protection of American troops in the South.

56 In Naim Molvan v. Attorney-General for Palestine, [1948] A.C. 351 (P.G.), the Zionist flag had no effective government to support it. No international issue was thus raised on this score by the seizure of the ship. 
recognition of insurgency and belligerency..$^{57}$ While for political reasons public proclamations of this kind are no longer made, ${ }^{58}$ recognition of "de facto governments," or of governments which do in fact control a given territory, or simple directions to maritime officials to respect the rights of the rebellious groups may serve the same purpose.

Next, there is the general problem of state responsibility for denial of justice. A state may have citizens to protect within the territory of an unrecognized state or that of a state with an unrecognized government. It may itself have assets to protect. As the Tinoco Arbitration ${ }^{59}$ shows, recognition (at least that of a government) is not necessary for the creation of state responsibility. As the arbitrator, William Howard Taft, said:

[W] hen recognition vel non of a government is by such nations determined by inquiry, not into its de facto sovereignty and complete governmental control, but into its illegitimacy or irregularity of origin, their non-recognition loses something of evidential weight on the issue with which those applying the rules of international law are alone concerned. ${ }^{60}$

Insofar as there are international rules dealing with the protection of individuals and their property, it would seem that international order would dictate that these attach to the benefit and detriment of all organized communities. A state may by political action prevent commercial intercourse or travel; it may summarily expel aliens; but where alien commerce, travel, or residence is permitted, it should be protected, at least on the secondary level of a remedy for "denial of justice."

Finally, there is the problem of sovereign immunity. Here both general and particular international law seem applicable. The need of domestic society for legal certainty and the administration of impartial justice is counterbalanced by the need of the international society for the prevention of potentially hostile confrontations.

The traditional jurisprudence provides a number of cases in which the sovereign immunity of unrecognized foreign governments has been protected. In Wulfsohn v. Russian Socialist Federated Soviet Republic ${ }^{61}$ the basis for this immunity was seemingly declaratory. The plaintiff was in a dilemma. He could not assert that the defendant did not exist;

57 Cf. LAUTERPACHT, op. cit. supra note 1, at 227-328.

58 Id. at 175-85.

5a Judicial Decisions Involving Questions of International Law, 18 AM. J. INT'L L. 147 (1924).

60 Id. at 154 .

61234 N.Y. 372,139 N.E. 732 (1923). 
yet in asserting his existence, he also necessarily asserted his immunity. British courts have relied more heavily than the American tribunals on the Foreign Office certificate as proof of immunity. The British Foreign Office, however, seems to issue these certificates more in the nature of a statement of fact than in the nature of a declaration of recognition. The facts stated may, indeed, conflict with its political policies and its policies regarding official recognition and the control of assets within the United Kingdom. In both The Christina ${ }^{62}$ and The Arantzazu Mendi ${ }^{63}$ the House of Lords recognized the sovereign immunity of the Spanish Nationalist Government, although the British Government refused to have direct relations with it or to recognize it diplomatically. Indeed, the ninth paragraph of the Foreign Secretary's certificate in the latter case shows that he viewed his function as only one of gathering facts for the courts, not one of determining legal questions:

(9) The question whether the Nationalist Government is to be regarded as that of a foreign sovereign state appears to be a question of law to be answered in the light of the preceding statements and having regard to the particular issue with respect to which the question is raised. ${ }^{64}$

This attitude of the Foreign Office, that it is only finding facts, is more consistent with a declaratory than with a constitutive view of the nature of recognition. ${ }^{65}$

Even the recent criticism of the use of sovereign immunity in what are essentially commercial cases has generally stopped short of advocating the physical levying of execution against property in the possession of a foreign sovereign. ${ }^{66}$ In one American case, ${ }^{67}$ the Department of State did not intervene to prevent trial or judgment, but did file a suggestion to prevent attachment of assets of the foreign state. Two British cases in the past decade seem to have turned on the question of

62 [1938] A.C. 485.

63 [1939] A.C. 256.

64 The Arantzazu Mendi [1938] P. 233, 242.

65 Of course, a state may extend immunity further than it is required to do by the genexal international law. When it does so, it is acting constitutively. The grant of immunity by the British courts to protected princes and their governments would come within this category. Duff Development Co. v. Kelantan Government, [1923] A.C. 395; Mighell v. Sultan of Johore, [1894] 1 Q.B. 149. Privileges granted to a resident government-in-exile might be another example.

66 Cf. Note, Sovereign Immunity, Waiver and Execution: Arguments from Continental Jurisprudence, 74 YALE L.J. 887, 910-14 (1965), which is critical of this practice.

67 Weilamann v. Chase Manhattan Bank, 192 N.Y.S.2d 469 (Sup. Ct. 1959). See also Drachsler, Some Observations on the Current Status of the Tate Letter, 54 AM. J. INT'L L. 790 (1960). 
fictional possession, ${ }^{68}$ but this distinction has now been authoritatively repudiated in favor of a general immunity against being impleaded. ${ }^{69}$ Either way, the courts are preventing open confrontations between state powers. While recognition is only indirectly involved in these cases, the dangers of physical confrontations are equally great regardless of the legal status of the government involved. A declaratory view seems necessary, although it may be supplemented with additional immunities.

Thus, in interstate relations, it seems that the declaratory theory must prevail. This does not, however, preclude the creation of international organizations as special personae in international law by constitutive means. Just as domestic legal systems first recognized only living persons and then later allowed the constitution of artificial corporations, international law may recognize communities which fulfill the requirements of states as its primary personae and also allow the constitution of organizations with international legal personality. ${ }^{70}$

\section{B. The External Sphere of Action: Political Questions}

Political questions are those issues in spheres of interstate relationships in which there are no existing clear legal obligations. Since they involve acts of states or governments vis-à-vis one another, one might argue that they are merely a subgroup of the previous classification. Since, by definition, these political questions involve issues where there is no strict international law duty to act or to refrain from acting, the effect of the law in this field is entirely different from that in the former field. Since there is no duty to act, refusal to act cannot be wrongful. And if refusal to act is not wrongful, despite the factual existence of state or governmental qualifications, then the standard involved is the equivalent of a constitutive one. ${ }^{71}$

Much confusion has been generated by the use of the word "recognition" to describe entry into diplomatic relations. The two concepts should be clearly distinguished, although the latter may correctly be called "diplomatic recognition" or "political recognition." Recognition of a state implies the acceptance by one state of another into the legal framework of international law. The recognized state becomes a crea-

68 Juan Ysmael \& Co. v. Indonesia, [1955] A.C. 72 (P.C.); United States v. Dollfus Mieg et Cie., [1952] A.C. 582.

69 Rahimtoola v. Nizam of Hyderabad, [1958] A.C. 379.

70 Cf. Reparation for Injuries Suffered in the Service of the United Nations, [1949] I.C.J. 174.

$\mathrm{T}_{1}$ It is not, strictly speaking, constitutive, since the action of the recognizing state does not "constitute" the recognized state in international law. For the recognizing state, however, the result is the same, since it is under no international duty to act. 
ture of that international law, capable of holding rights and duties under it. Recognition of a government is acceptance of it as the lawful agent of that state. The establishment of diplomatic relations is, however, only the creation of formal means of communication between the governments of two states. Abstention from diplomatic intercourse may imply political and possibly total nonintercourse between two states, but it need not imply nonrecognition. The breach of diplomatic relations can imply nonrecognition only when the government in one of the states has never been recognized by the government in the other, and even then the nonrecognition is only at the governmental and not at the state level. If a changing policy occasions the breach, but there is continuity of personnel administering the states involved, governmental recognition clearly continues.

Entry into diplomatic relations is certainly not required by positive international law. Indeed, for most states the entry into direct diplomatic relations with every other state would be a practical impossibility. For the major powers and for those having regular dealings with one another, regular diplomatic communication is certainly desirable, but even in its absence communication between states is usually possible. This can be by informal negotiations carried on by commissioners, ${ }^{72}$ or by conferences at third capitals or at international assemblies, ${ }^{73}$ or through the use of the good offices of some third state. ${ }^{74}$ At worst diplomatic nonintercourse causes serious inconvenience. It is a situation which should be avoided as far as possible, especially by the major powers, but it cannot be described as illegal.

The exchange of diplomatic representatives has frequently been used to imply recognition of a foreign state or its government. Indeed, it has sometimes been used, especially in inter-American relations, to imply approval of a new government. Similarly, the withholding of representation has been used to express disapproval of the political situation obtaining within some other state. ${ }^{75}$

There has been one recent proposal for a differentiated policy of recognition (presumably meaning "political recognition") within the western hemisphere. ${ }^{76}$ Under this proposal, American nations could express their collective disapproval of antidemocratic revolutions within

72 As in the case of the Eastern European states before their recognition. THE LAW of Nations 107 (Briggs ed. 1952).

73 As in the case of the American-Chinese exchanges at Warsaw.

74 As is usually the case when there has been a rupture of diplomatic relations, e.g., the Swiss representation of United States interests in Cuba and vice versa.

75 See authorities cited notes 38 \& 39 supra.

76 Fenwick, The Recognition of de facto Governments: Is There a Basis for Inter-American Collective Action?, 58 AM. J. INT'L L. 109 (1964). 
the hemisphere by withholding or restricting diplomatic representation. The proposal leaves, however, a number of questions unanswered. Are the laws of the unrecognized government ${ }^{77}$ to be given extraterritorial effect in the nonrecognizing states? Is the property of the state with the unrecognized government to be frozen as ownerless in the nonrecognizing states? The exact extent of this nonrecognition is unspecified.

According to Fenwick, a proponent of collective and public denunciation of undesirable governments, ${ }^{78}$ past examples indicate that nonrecognition, if only it had been collective, would have been successful. Two reasons make this solution undesirable: one of them is applicable if it is effective, the other if it is ineffective.

If this sort of nonrecognition is effective, it tends to subvert national sovereignty. In itself, this is no shortcoming in a world which is increasingly relinquishing national claims for regional and global ones. Collective diplomatic disapprobation by a regional or global organization is certainly to be preferred to that by a single state. Nevertheless, until there is more general consensus on particular regional or global standards of legitimacy, such interference is of questionable justification. Is the international body to decide on the basis of the degree of consent of the population to the new government, or is it to decide on the basis of the social program of the new government? Fenwick leaves these questions unanswered, giving only a political method for determining the result, not a rule by which it is to be determined.

The more serious obstacle to such a policy of nonrecognition is that of its probable ineffectiveness. Fenwick may be too optimistic in his appraisal of the effectiveness of collective action. New regimes may seek recognition by other powers to strengthen their internal positions. Nevertheless, nonrecognition in the inter-American context has generally meant only the withholding of exchange of diplomatic representatives and the withholding of entry into political relations. While either of these policies may hurt a new government, neither is necessarily fatal. Unless the nonrecognizing states are willing to take steps to impose an effective nonrecognition by the imposition of embargoes and the refusal of transit facilities, and to make this nonrecognition effective against extra-American powers, a policy of nonrecognition will frequently (although not always) be ineffectual. As Williams said of the Stimson Doctrine, "the mere blowing of horns is of little value unless the blowers are prepared to follow up their notes in some effective

77 In the inter-American case only governmental recognition would seem likely to arise.

78 Fenwick, supra note 76 , at 111 . 
manner.'79 Indeed, the American position on China shows that such trumpeting may inextricably involve one in a melody of disapprobation, long after the tune has become monotonous. The seeming failure of nearly total global nonrecognition of the independence of Southern Rhodesia to provide more than marginal effects on the government or economy of that territory should serve as a warning to those who have hopes for the democratizing effects of such a policy..$^{80}$

Thus, even the political effect of diplomatic nonrecognition may be dubious. It should, however, be clear that the failure to exchange representatives or the withdrawal of diplomatic representation already granted has no necessary legal consequence. This, like the negotiation of treaties and the granting of visas (to name only two obvious examples), is a discretionary matter. Since it is discretionary, a declaratory standard for this class of recognition would be meaningless.

\section{The Internal Sphere of Action}

When the scene of contest changes from that external to the recognizing state to that internal to it, other considerations apply. No longer is the main consideration that of the preservation of international peace; there are also considerations of the type of internal order which the recognizing state wishes to preserve. In this sphere of action, more than in the previous ones, one must examine the particular international law of each state, and try to distill a general standard from basic agreements. Whether each of these particular standards is sufficient to meet the minimum general standard thus obtained will raise questions of state responsibility.

Within this category, three types of cases arise. First, there are those

79 Williams, Some Thoughts on the Doctrine of Recognition in International Law, 47 HARV. L. REv. 776, 791 (1934).

80 See U.N. Sec. C. Res. No. 232 (1966), implemented in the United States by Exec. Ord. No. 11322, 32 Fed. Reg. 119 (1967).

Along these lines, Fenwick questions the justice of imposing treaty obligations upon a state which has an unrepresentative government. He would argue that nonrecognition of these regimes would prevent the imposition of onerous obligations upon an unwilling populace. Fenwick, supra note 76, at 111 . However well-meaning, this seems an erroneous argument. Recognition does not impose treaty obligations: the negotiation of treaties does. Neither recognition nor the exchange of diplomatic representatives implies the negotiation of treaties. Indeed, unless some way is found to make the negotiation of treaties impossible not only for nonrecognizing states but for all others as well, there is no improvement in the situation of the oppressed people of the unrecognized state, for states which would be willing to enter into treaties with unrepresentative regimes would presumably not cooperate in a policy of nonrecognition. To be effective, Fenwick's collective nonrecognition would have to be universal, binding not only other American states (whether or not they favored the policy) but also all other states (even though they did not participate in the determination). 
cases in which unrecognized governments have applied their law to persons or chattels physically within their jurisdiction, which later come within the nonrecognizing jurisdiction. Second, there are those cases in which an unrecognized government seeks to affect persons, chattels, or choses in action within the nonrecognizing state through extraterritorial application of its own law. Finally, there are those cases in which the unrecognized government seeks to participate directly, either by entering into contracts or by claiming assets standing in the name of the state.

1. Adjudications Regarding the Operation of Foreign Law in Foreign Territory. In the first of these cases, legislation or adjudicative action may operate to change the status or rights and duties of persons or the ownership of property physically under the control of an unrecognized government, whether in a recognized or an unrecognized state. In such cases the courts of another state are involved only if the persons or chattels later come within their jurisdiction. The effect of the legislation is not really extraterritorial; indeed it is, in its first application, purely internal.

In these cases, both commercial and general convenience dictate that a declaratory approach be used, although the authority making the declaration of fact need not be the courts. Persons are married and divorced, are born and die, without respect to the international status of the government under which they live. Property is bought and sold in a like manner. General convenience would dictate that these ordinary human transactions be given their ordinary consequences, without regard to the political constitution under which they take place. Commercial convenience, which requires rules like those protecting the purchaser for value in domestic systems, ${ }^{81}$ would seem to indicate that this is a useful rule for the international legal system.

Where the acts brought into question would ordinarily be recognized in a domestic court if the state were recognized, there seems to be little controversy that the courts should enforce the foreign act, even though the government there is not officially and formally recognized for political purposes by the foreign office of the forum state. ${ }^{82}$ Justice

81 Cf. UnIForMr CoMmercial CODE \$ 2-403(I).

82 The locus classicus of this doctrine is the statement of Chief Judge Pound of the New York Court of Appeals in Salimoff v. Standard Oil, 262 N.Y. 220, 226-28, 186 N.E. 679, 682-83 (1933):

"As a juristic conception, what is Soviet Russia? A band of robbers or a government? We all know that it is a government. The State Department knows it, the courts, the nations and the man on the street. If it is a government in fact, its decrees have force within its own borders and over its nationals. ...

"The legitimate conclusion is that the existing government cannot be ignored by the courts of this state, so far as the validity of its acts in Russia are concerned. . . . 
Breitel of the New York Appellate Division recently summarized this doctrine in a case involving a commercial transaction in which the East German government had been involved:

A foreign government, although not recognized by the political arm of the United States Government, may nevertheless have de facto existence which is juridically cognizable. The acts of such a de facto government may affect private rights and obligations arising either as a result of activity in, or with persons or corporations within, the territory controlled by such de facto government. ${ }^{83}$

Until the recent decision of the House of Lords in Carl-Zeiss Stiftung v. Rayner of Keeler Ltd., ${ }^{84}$ the British cases appeared to indicate a similar development. ${ }^{85}$ Indeed, in his speech in judgment, Lord Wilberforce indicated that the question might still be open in Britain, due to the fictions used in the determination of the instant case. ${ }^{86}$ The British courts did not themselves take judicial notice of political conditions in overseas areas, but rather left this factual determination to the conclusive statement of the Foreign Office. The Foreign Office, in its turn,

"Nonrecognition is no answer to defendant's contention, no reason for regarding as of no legal effect the laws of an unrecognized government ruling by force, as the Soviet government in Russia concededly was. 'Within its own territory the Soviet was a sovereign power." "'

83 Upright v. Mercury Business Machines Co., 13 App. Div. 2d 36, 38, 213 N.Y.S.2d 417, 419 (1961).

84 [1966] 3 W.L.R. 125 (H.L.). The case reached the House of Lords on a procedural point. To use American terminology, the defendants had moved to dismiss the suit (which was for infringement of a trademark) on the ground that the plaintiff had not consented to the filing of the action by the solicitors who had obtained the summons (writ). Whether the plaintiff had consented to the suit turned upon the composition of the governing board of the Zeiss Foundation; this question turned upon East German legislation reorganizing certain local governmental units. (A second issue of estoppel by foreign judgment is not relevant here). The defendants first raised the recognition point in the Court of Appeal, which requested a certificate from the Foreign Office. [1965] 1 Ch. 525 (C.A.). The Court of Appeal then held that, since the East German government was unrecognized, its legislation could not be noticed, and therefore the plaintiff had not consented to the suit. [1965] I Ch. 596 (C.A.). On appeal, the House of Lords held that, although the East German government was unrecognized, it could be construed to be the agent of the Russian government, and its legislation could be noticed. The case was remanded for trial on the merits. For a discussion of the case, see Greig, The Carl Zeiss Case and the Position of an Unrecognized Government in English Law, 83 L.Q. REv. 96 (1967).

85 Thus, in Luther v. Sagor, [1921] 1 K.B. 456, the trial court refused to recognize an expropriation by the Communist government in Russia, but when the Foreign Office certified to the Court of Appeal that the Soviet government was actually in control of the territory, it reversed the decision. [1921] 3 K.B. 532 (C.A.). For the certificate, see [1921] id. at 536-537. In that case, however, the agreement according recognition had been expressly limited so that the laws of neither state would have extraterritorial effect in the other state.

86 [1966] 3 W.L.R. 125, 178 (H.L.). 
seems to have been willing to certify facts which were not necessarily in accordance with the official political recognition policies of the government. ${ }^{87}$ In the Carl-Zeiss case, on the other hand, the Foreign Office did not state the factual conditions obtaining in East Germany, but rather gave its conclusions as to the legitimacy of the East German government. ${ }^{88}$ Whether this was due to a change in British recognition policy ${ }^{89}$ or to the failure of the Court of Appeal to put the correct question to the Foreign Office ${ }^{90}$ is unclear. ${ }^{91}$

Other recent British cases show that, at least after the government has granted political recognition to a foreign government, the highest British tribunal will differentiate between two classes of cases. Foreign legislation is effective for the internal purposes of the foreign state from the date of effective occupation of the territory by the new government,

87 See the certificate paraphrased in Banco de Bilbao v. Sancha, [1938] 2 K.B. 176, 181: "[T] hat the Government set up by General Franco in the Basque country since his capture of Bilbao on June 19, 1937, is now recognized by His Majesty's Government as the Government which exercises de facto administrative control over a considerable portion of the Basque country, including Bilbao. . . . It appears that notwithstanding recognition by His Majesty's Government of the de facto position of General Franco's Government in this area, His Majesty's Government recognises the Republican Government of Spain as the de jure Government of the whole of Spain including the area in which it recognizes General Franco's Government as exercising de facto administrative control." $C f$. the certificate in The Arantzazu Mendi [1938] P. 232, cited in part in text accompanying note 64 supra.

88 The certificate is set out in part in the judgment of Lord Justice Harman, [1965] Ch. 596, 637-638: "Since June 1945 'and up to the present date, Her Majesty's Government have recognized the State and Government of the Union of Soviet Socialist Republics as de jure entitled to exercise governing authority in respect of that zone. In matters affecting Germany as a whole, the States and Governments of the French Republic, the United Kingdom of Great Britain and Northern Ireland, the United States of America, and the Union of Soviet Socialist Republics were jointly entitled to exercise governing authority. In the period from August 30, 1945, to March 20, 1948, they did exercise such joint authority through the Control Council for Germany. Apart from the States, Governments and Control Council aforementioned, Her Majesty's Government have not recognised either de jure or de facto any other authority purporting to exercise governing authority in or in respect of the zone." "

89 As Lord Reid seems to indicate at [1966] 3 W.L.R. 137, in citing a 1951 speech by Mr. Herbert Morrison, then Foreign Secretary. It should be noted that the British and American Governments seem to refuse political recognition in apparently similar quantities. Neither recognizes North Viet Nam, North Korea, or East Germany. The United States does not recognize Communist China, while the United Kingdom does not recognize Nationalist China.

90 One can only conjecture what (if any) reply the Foreign Office would have made to a question put thus: "Do the authorities calling themselves the German Democratic Republic exercise effective governmental control in the relevant territory?"

91 By importing an additional consideration, the House of Lords reached a conclusion not inconsistent with that urged by this comment. The House found the East German law effective because the Russians were the legitimate authority and the German Democratic Republic was presumably acting as their agent. In the instant case the "agency" may be real, but in some future case could an "agency" be presumed where none exists? If so, the effective government might always be recognized. 
while extraterritorial effectiveness is postponed until the date of formal recognition. ${ }^{92}$ In cases involving internal effectiveness, the Foreign Office statement is apparently treated as a conclusive statement of fact, while in those involving extraterritorial application, the certificate is apparently treated as of constitutive effect. In other words, in the one set of cases, recognition is declaratory, while in the other it is constitutive.

Treating the problem solely in terms of recognition overlooks two vitally important factors in the decision of many of the cases involving property rights. These are the actions of foreign states which are contrary to the minimum standards of international law and actions of foreign states which are contrary to the public policy of the forum state. The most recent cases to arise in these fields have involved recognized, rather than unrecognized, states or governments, ${ }^{93}$ but their import makes their treatment here necessary.

In his dissent in Banco Nacional de Cuba v. Sabbatino, ${ }^{94} \mathrm{Mr}$. Justice White canvasses the problem of foreign acts contrary to minimum standards of international law..$^{95} \mathrm{He}$ argues that the courts are required to adjudicate cases and must take general international law into account in such adjudication. While this may be true, it is also arguable that the taking of private property by the state is not illegal, but only the denial of compensation makes it so. If this is the case, the expropriating state may be liable for compensation, without giving the former owner recourse against the goods themselves. A claim against the state for liquidated damages would, of course, be unenforceable because of the defense of sovereign immunity. ${ }^{96}$ Justice Harlan, speaking for the majority of the Supreme Court, cogently argued that, while the general international law might treat the expropriation as a delict, it could not

92 Gdynia-Ameryka Linie v. Boguslawski, [1953] A.C. 11 (H.L.); Civil Air Transport Inc. v. Central Air Transport Corp., [1953] A.C. 70 (P.C.).

93 Bernstein v. Van Heyghen Freres S. A., 163 F.2d 246 (2d Gir. 1947) and Bernstein v. N.V. Nederlandsche-Amerikaansche Stoomvaart-Maatschappij, 173 F.2d 71 (2d Cir. 1949), 210 F.2d 375 (2d Cir. 1954) (confiscation by recognized, but enemy, government); and Banco Nacional de Cuba v. Sabbatino, 376 U.S. 398 (1964) (expropriation by recognized but unfriendly, government).

94376 U.S. 398, 439 (1964). The case involved the nationalization of sugar aboard a ship in Cuban territorial waters. The Supreme Court applied the "act of state" doctrine and acknowledged the validity of the seizure. For subsequent related litigation, see Banco Nacional de Cuba v. Farr, 243 F. Supp. 957 (S.D.N.X. 1965).

95 Banco Nacional de Cuba v. Sabbatino, 376 U.S. 398, 450-56 (1964).

96 Compare the position of the previous owner of goods sold under a statutory provision giving the innocent purchaser for value good title despite the voidable title of his vendor. He has no recourse against the goods or against their new owner. His only remedy is damages against the vendor for conversion. This may be equally futile, since such a vendor usually has either absconded or has dissipated the proceeds. 
compel the domestic or particular law to treat it as invalid: "[T]he public law of nations can hardly dictate to a country which is in theory wronged how to treat that wrong within its domestic borders." 97

For suits instituted before 1966, Congress authoritatively accepted the view of Mr. Justice White. By the Hickenlooper amendment to the Foreign Aid Act of 1964, it required the courts to adjudicate the validity of such seizures at international law. ${ }^{98}$

The second argument, based on the public policy of the forum state, is less appropriate where the expropriation takes place in foreign territory than where the expropriating state attempts to extend its laws extraterritorially. It will be discussed in more detail in connection with the latter class of cases. In making a determination about the legal efficacy of acts which happened abroad, the courts are essentially determining factual issues (who was "owner" or "possessor" when the property entered this jurisdiction?) and not legal ones (was that ownership rightfully acquired?). ${ }^{99}$

From a more practical point of view, considerations of justice and the efficiency of its administration would seem to indicate that more equitable results can be reached through the consolidation of claims by the State Department, acting in the nature of a trustee in bankruptcy, than by allowing each individual claimant to pursue assorted chattels throughout the world. International trade would be complicated by leaving the pursuit to the individual. While trade is not the ultima ratio of international law, neither should its claims be lightly ignored. More substantial justice is provided for all claimants if it is rendered without the accident of the presence of expropriated goods within the jurisdiction.

Thus, a declaratory view is suggested for the recognition of governmental actions which take their immediate effect within the territory controlled by the unrecognized government. This view has a rationale

97376 U.S. 398,423 (1964).

9822 U.S.C. $\$ 2370($ e)(2) provides: "Notwithstanding any other provision of law, no court in the United States shall decline on the ground of the federal act of state doctrine to make a determination on the merits giving effect to the principles of international law in a case in which a claim of title or other right is asserted by any party including a foreign state (or a party claiming through such state) based upon (or traced through) a confiscation or other taking after January 1, 1959, by an act of that state in violation of the principles of international law, including the principles of compensation and other standards set out in this subsection: Provided, That this subparagraph shall not be applicable . . (3) in any case in which the proceedings are commenced after January 1, 1966."

89 If, at the relevant time, the property is within a third state, then the question of recognition or nonrecognition of the extraterritorial character of the legislative acts of an unrecognized government should turn on the status of that government in the eyes of the third state and the applicable public policy there. 
different from that suggested above for external acts of governments. That was largely based on a need to prevent hostile confrontations between governments; this is based on commercial convenience and general public utility.

2. The Extraterritorial Application of Foreign Law in Domestic Territory. In the second type of case arising in the internal sphere of action, the goods or other rights to which the foreign government seeks to transfer title or with which it otherwise attempts to deal are physically located within the nonrecognizing state. Here other considerations of domestic public policy apply. As Mr. Justice Stone said in answering a claim to general retroactivity ${ }^{100}$ of recognition in Guaranty Trust Co. v. United States:

The argument thus ignores the distinction between the effect of our recognition of a foreign government with respect to its acts within its own territory prior to recognition, and the effect upon previous transactions consummated here between its predecessor and our own nationals. The one operates only to validate to a limited extent acts of a de facto government which by virtue of the recognition, has became a government de jure. But it does not follow that recognition renders of no effect transactions here with a prior recognized government in conformity to the declared policy of our own Government. The very purpose of the recognition by our Government is that our nationals may be conclusively advised with what government they may safely carry on business transactions and who its representatives are. If those transactions, valid when entered into, were to be disregarded after the later recognition of a successor government, recognition would be but an idle ceremony, yielding none of the advantages of established diplomatic relations. ... .101

Thus in cases involving extraterritorial operation of foreign laws or direct involvement of the foreign government in commercial transactions, the political recognition will be the controlling factor, if the application of the foreign law or the transaction involved is to take place within the forum state.

100 Many of the cases speak of "retroactivity" of the official political recognition. This is only because of the time sequence involved in them. Before the litigation commenced (or before it reached the appellate level), political recognition was granted. Hence the question could be framed as one of retroactivity of the political recognition, rather than as one of the immediate efficacy of a government within its territory. For a case in which governmental efficacy was the test, despite continuing political non-recognition, see Upright v. Mercury Business Machines Co., 13 App. Div. 2d 36, 213 N.Y.S.2d 417 (1961); note 83 and accompanying text supra.

101304 U.S. 126, 140 (1938). 
Here questions of the public policy of the forum state must be more closely considered. Domestic courts are being asked directly to enforce foreign law, not merely to recognize the enforcement of it by the foreign state. $^{102}$ The public policy of the forum state must be taken into consideration. ${ }^{103}$

If transactions take place within a nonrecognizing state, based on legal titles existing there at the time of the transactions, it would seem inconvenient and unjust for retroactivity of recognition to invalidate these transactions and the titles created by them. If property is held in the name of a state or of a foreign corporation or citizen, the purchaser of such property should not be put to the risk of the vagaries of foreign affairs. If the government of the forum state gives political recognition to the old regime as the lawful government of some territory, it seems inconsistent that it can later divest those who relied upon its determination of their titles to property.

On the other hand, if the title to the property remains in the foreign state, its corporations, or citizens at the time of granting of political recognition, the new government can take action regarding it. Indeed, its earlier laws, ineffective in the forum state until the granting of political recognition, can take effect at that time. This was the situation

102 See Republic of Iraq v. First Nat'l City Bank, 353 F.2d 47 (2d Cir. 1965), in which the Second Circuit refused to allow enforcement of an Iraqi decree confiscating the property of the deposed (and deceased) monarch, King Faisal, including some in the possession of a New York bank, because confiscation-even of the property of a head of state-was contrary to our public policy.

The refusal of courts to enforce foreign revenue or penal legislation is another example of the reluctance of our judicial authorities to apply laws contrary to local public policy, although Mr. Justice White in Sabbatino cites it for the opposite proposition. If the transfer of title contemplated by such legislation has been perfected by the competent courts within the foreign territory, American courts will not go behind the declaration. See Wisconsin v. Pelican Ins. Co., 127 U.S. 265, 291 (1888): "It is true that if the prosecution in the courts of one country for a violation of its municipal law is in rem, to obtain a forfeiture of specific property within its jurisdiction, a judgment of forfeiture, rendered after due notice, and vesting the title of the property in the State, will be recognized and upheld in the courts of any other country in which the title to the property is brought in issue." The other Supreme Court cases cited by Mr. Justice White in Sabbatino, 376 U.S. 398, 448 n.9, all turn on the failure of the foreign state to perfect its claim within its own territory before asserting it within the United States. The Antelope, 23 U.S. (10 Wheat.) 66 (1825); Huntington v. Attrill, 146 U.S. 657 (1892); cf. Moore v. Mitchell, 30 F.2d 600 (2d Cir. 1929).

103 In spite of the seemingly contrary rule in Erie Railroad v. Tompkins, 304 U.S. 64 (1938), American courts have applied a national public policy, rather than the public policies of the several states. See Jessup, The Doctrine of Erie Railroad v. Tompkins Applied to International Law, 33 AM. J. INT'L L. 740 (1939), and Henkin, The Foreign Affairs Power of the Federal Courts: Sabbatino, 64 CoLum. L. REv. 805 (1964). This is surely a peculiarly local problem, not relevant to general international law. Strong arguments for it are given in United States v. Pink, 315 U.S. 203, 221-26 (1942), and Banco Nacional de Cuba v. Sabbatino, 376 U.S. 398, 425-27 (1964). 
in United States $v$. Pink..$^{104}$ No attempt was made by the United States Government to recover assets which had been actually disbursed by the receiver for the Russian insurance company before the date of the Litvinov assignment. Justice Douglas, in the opinion of the Court, skirted the question of whether the other disbursements ordered by the New York court had "vested,"105 but the assumption seems to have been that, because of the intervention of the United States before the distribution was actually made, they did not. Thus, the Court treated the undistributed assets of the insurance company as the property of the Soviet Government at the time of political recognition.

British courts have followed the same distinction between acts which take place abroad and those which can take effect only through extraterritorial operation of legislation within the United Kingdom. In Gdynia-Ameryka Linie v. Boguslawski ${ }^{106}$ the House of Lords differentiated between those acts of the Polish government which took place within the territory under its immediate control, which were valid from the beginning of such control, and those acts which could only take effect outside of Polish territory, through extraterritorial operation of Polish law, which were valid only from the date that formal recognition was conferred. Lord Oaksey specifically said, "I . . . support the view that retroactivity of recognition should be confined to spheres of de facto control."107 Lord Porter drew the same distinction on the basis of an apparently fictional criterion of control. ${ }^{108} \mathrm{~A}$ similar result was reached by the Judicial Committee of the Privy Council in Civil Air Transport Inc. v. Central Air Transport Corp. ${ }^{109}$ in which Viscount Simon, speaking for the Board, said, "[T]he validity of the transaction must be judged as at the date when it was entered into, and not in the light of subsequent events, which might have turned out differently."110

Continental courts have generally followed a practice similar to that of the American and British courts in refusing to recognize the extraterritoriality of decrees of unrecognized governments. Thus, the Czarist law regarding corporations or property was applied by French, Belgian,

104315 U.S. 203 (1942).

$105 I d$. at $226-228$.

106 [1953] A.C. 11 (H.L.).

107 Id. at 39.

108 "Therefore, although I am prepared to accept that the recognition of the new government dates back to June 28 in Poland where that government had effective control, I am of the opinion that that control did not extend to the old government or the Polish merchant fleet and its personnel until July 6 ...." Id. at 29. June 28 was the date upon which the new government began operation in Poland. July 6 was the date upon which it was politically recognized by Great Britain.

109 [1953] A.C. 70 (P.C.).

$110 \mathrm{Id}$. at 91. 
Italian and Egyptian courts during the decade after the Czarist government had ceased to exist. ${ }^{111}$ Mann was able to cite only one Swiss case in which a different result was reached, ${ }^{112}$ and suggests that German and Austrian courts may have pursued the same line of reasoning. Lauterpacht found one Dutch case in the same vein. ${ }^{113}$ Even if international practice varies, it does not disprove this thesis, since the particular international law of some states might vary from the general standard. In matters involving private law, the general international law provides only a broad minimum framework, but not necessarily the explicit norms.

A constitutive view is hence indicated, but not required, in these cases, since it is not reasonable to ask the domestic courts of one state to sit in judgment on the political quarrels of another. Such action would be as unfortunate diplomatically as it would be inappropriate judicially. In the first type of cases involving internal legal action in the foreign state, judicial determination of a state of facts was necessary. That determination did not extend to questions of legitimacy, which are not easily justiciable. Barring authoritative international determination regarding recognition (an improbable solution, given present circumstances), certification of recognition by each foreign office seems the only practical course of action. During a period of internal conflict in some foreign state, courts in another state can simply block the assets of that state, to await the outcome there. ${ }^{114}$ Such a course of action would seem unwise, for it obstructs a government still recognized as legitimate by the forum state, and thus gives implicit assistance to the insurgency.

Thus recognition must take on a constitutive character when the immediate problem is the extension of the effectiveness of foreign law into the recognizing state. And here political recognition may play some role as evidence of the constitutive act.

3. Direct Participation of the Foreign State in Domestic Courts. The third type of internal case, mentioned above, involves direct participation by the foreign state. Here the same considerations seem to apply

111 See the cases cited by Mann, Judiciary \& Executive in Foreign Affairs, 29 Transactions OF THE Grotius Society 143, 168 (1943).

$112 I d$. at 158. This case involved a divorce sought in Switzerland by one Russian against another. Swiss law would allow the divorce of foreigners only if the home state of the parties would recognize it. Thus the case did not directly involve extraterritorial application of the legislation of the unrecognized government.

113 LAUTERPACHT, RECOGNITION IN INTERNATMONAL LAW 153 (1947).

114 Bank of China v. Wells Fargo Bank, 92 F. Supp. 920 (N.D. Cal. 1950); a similar result was accomplished by the delay between trial and appeal in Luther v. Sagor, [1921] I K.B. 456, [1921] 3 K.B. 532 (C.A.); and in Haile Selassie v. Cable and Wireless, Ltd. [1939] $1 \mathrm{Ch}$. 182 (G.A.). 
as in the immediately previous sub-class, and recognition again appears to be constitutive in nature. American, British, and Norwegian courts have refused to allow suits to be brought by unrecognized foreign governments. ${ }^{115}$ The dictum of Mr. Justice Stone in Guaranty Trust Co. $v$. United States quoted above applies directly.

If no government is recognized politically, the result would apparently be to block the assets of the state, leaving them in the hands of whatever private custodians may have possession. If some government is officially recognized by the foreign office, it will be able to dispose of the state assets, whether it is in actual control of the state territory or not. Such an authoritative and public decision about recognition seems preferable to leaving the question to the private judgment of the custodians where the transfer of ownership is irregular. If the state in which the assets are located wrongfully neglects to make a declaration of recognition for this purpose, it may be incurring an international delict analogous to denial of justice. This responsibility should not be extended to each private custodian or purchaser.

\section{Conclusion}

To find the true nature of recognition, one must examine its several functions. Such examination shows that both constitutive and declaratory theories have some, but not total, validity. Three main functions of recognition must be separately considered:

A. In the general international law which imposes state responsibility for external actions, recognition is granted by a declaratory process. Such an approach is necessary in order to avoid the possibility of hostile confrontations. Any community which meets the standards of statehood must be treated with all the respect due to a foreign state.

B. This declaratory standard does not apply to matters which international law leaves to the discretion of each state, such as the exchange of diplomatic representatives, which may be called political recognition. Since these matters are merely discretionary, the constitutive theory provides a better description of them.

C. In cases involving private law transactions, considerations of commercial and general convenience dictate that acts of an unrecognized government taking effect upon persons or chattels within its physical control be recognized if these persons or chattels later come within another jurisdiction. Hence, recognition of foreign acts which take

115 Russian Socialist Federated Soviet Republic v. Cibrario, 235 N.Y. 255 (1923), 139 N.E. 259; Gity of Berne v. Bank of England, 9 Ves. Jun. 347, 32 Eng. Rep. 636 (Ch. 1804); Spanish Gov't v. Campuzano, Annual Digest 1938-1940, cas. no. 27 (Sup. Ct. Norway 1938). See also Nö̈L-HENRY, LES GOUVERNEMENTS DE FAIT DEVANT LE JUGE 125-27 (1927). 
place abroad is properly declaratory. The same considerations, however, dictate the opposite result in relation to acts-in-the-law of the nonrecognizing state, especially when the unrecognized government attempts to apply its legislation or directly to claim assets located in the nonrecognizing state. Here recognition is properly constitutive.

The current problems in the Middle East (which most recently erupted after the copy for this comment was out of the hands of the author) can illustrate the first two of these points. No one can doubt that Israel exists in fact. The declaratory approach, summarized in point $A$, requires that other states recognize the territorial integrity and other fundamental rights of Israel. Only by such action can wars like the brief but bloody Arab-Israeli conflict of this year be prevented. It is the existence of Israel, and not its legitimacy in the eyes of the Arabs, which gives its military forces the capability to attack and to defend. As point $B$ indicates, the Arab states need grant nothing further than these bare fundamental rights. They need not enter into diplomatic relations, trading agreements, treaties, or grant other concessions which are discretionary. Of course, a problem of classification arises: Is Egypt required by international law to grant passage through the Straits of Tiran or is that simply a matter of discretion? Such questions raise fresh problems of international law which are beyond the scope of this comment. 